\title{
PENDIDIKAN KESEHATAN PADA PEREMPUAN MENOPAUSE TENTANG SCREENING KESEHATAN REPRODUKSI DI TANGERANG
}

\author{
${ }^{1}$ Eva Berthy Tallutondok., ${ }^{2}$ Fransiska Ompusunggu., ${ }^{3}$ Prisca Adipertiwi Tahapary \\ ${ }^{4}$ Belet Lydia Ingrit., ${ }^{5}$ Dwi Yulianto Nugroho \\ 1,2,3,4,5 Fakultas Keperawatan - Universitas Pelita Harapan \\ eva.tallutondok@uph.edu, belet.ingrit@uph.edu, fransiska.ompusunggu@uph.edu, \\ prisca.adipertiwi@uph.edu, dwi.nugroho@uph.edu
}

\begin{abstract}
Abstrak
Menopause merupakan proses berhentinya siklus menstruasi selama 12 bulan berturut-turut secara alamiah yang terjadi pada seorang perempuan. Walaupun kejadian alamiah, namun menopause dapat memengaruhi adaptasi fungsi tubuh sehingga perempuan harus mengetahui dampak menopause yang terjadi. Akan tetapi, kajian tentang menopause masih jarang dilakukan di masyarakat sehingga diperlukan kegiatan pengabdian kepada masyarakat berupa pendidikan kesehatan dan screening kesehatan reproduksi pada perempuan yang bertujuAN untuk meningkatkan pengetahuan perempuan tentang dampak menopause dan mau melakukan screening kesehatan reproduksi. Pelaksanaan pendidikan kesehatan ini dilakukan dengan pendekatan tanya jawab dengan partisipan usia 30-74 tahun dan belum pernah dilakukan operasi pengangkatan organ sistem reproduksi. Hasil diketahui responden sangat antusias pada diskusi awal ( pre) melalui beberapa pertanyaan yang disampaikan oleh peserta terkait pengalaman pribadi (11\%) dan meningkat pengetahuan (22\%) setelah diberikan edukasi dengan menjawab benar setiap pertanyaan selama proses edukasi. Artinya ada peningkatan pengetahuan responden dua kali lipat, tetapi tidak sejalan dengan perilaku responden melakukan screening kesehatan. Hal ini dibuktikan hanya ada (66.67\%) saja yang mengikuti screening kesehatan reproduksi, sehingga disimpulkan bahwa pemberian edukasi dalam waktu singkat dan tidak berkesinambungan tidak efektif terhadap perubahan sikap dan perilaku responden untuk informasi baru.
\end{abstract}

Kata Kunci : Pengetahuan, Menopause, Screening kesehatan

\section{PENDAHULUAN}

Menopause merupakan suatu proses alamiah yang harus dialami oleh setiap wanita dalam kehidupannya yang biasanya akan diketahui setelah setahun tidak mengalami menstruasi secara terus menerus (Astutik \& Suparni, 2016). Saat memasuki masa menopause ada wanita yang menyambutnya dengan biasa saja karena menganggap kondisi tersebut sebagai bagian dari siklus kehidupan alamiah sehingga menimbulkan stress karena berakhirnya masa reproduksi dan penurunan fungsi organ - organ tubuh (Dewi, 2018).
Pada masa menopause seorang wanita mengalami keluhan yang dapat mengganggu aktifitas sehari-hari (Debby, 2012). Keluhan tersebut diakibatkan karena adanya perubahan pengeluaran hormon yang diproduksi ovarium yaitu estrogen dan progesteron yang berperan penting sebagai neuroprotektif dan memicu proses sinaptogenesis didalam otak (Henderson, 2009).

Masa transisi dari periode produktif ke non produktif menuntut penyesuaian diri terhadap perubahan fisik dan peranan wanita menopause. Hal tersebut dapat dihadapi dengan bergantung pada kestabilan emosi dan sikap, gaya hidup dan 
pengalaman masa lalu yang berasal dari intenal wanita menopause dan lingkungan sosial yang menyertainya. Aktivitas fisik dan perubahan gaya hidup dengan kualitas yang baik juga dapat memanajemen penurunan fungsi kognitif pada masa menopause (Tan, 2014).

Kemampuan kognitif yang menurun dapat memengaruhi kehidupan wanita yang mengalami menopause (Henderson, 2009). Hal tersebut dipicu oleh ketidakstabilan hormon yang memengaruhi kemampuan kognitif di otak yaitu hormon estrogen yang memegang peranan penting dalam fungsi otak (Susilowati \& Istianah, 2012).

Beberapa faktor yang mempercepat seorang wanita mengalami menopause, diantaranya adalah usia saat haid pertama, usia melahirkan, jumlah anak, pemakaian kontrasepsi, beban pekerjaan, merokok, dan alkohol. (Ariyanti \& Apriliana, 2016). Tanda dan gejala seperti panas, berkeringat, moody, dan penurunan fungsi kognitif akan dialami oleh wanita menopause, namun keadaan tersebut merupakan reaksi respon tubuh terhadap perubahan fisiologis sistem reproduksi dan sistem hormonal (Epperson, Amin, Ruparel, Gur, Loughead, 2012).

Perubahan hormon yang berperan penting pada wanita menyebabkan perubahan fisik dan psikologis yang memengaruhi keadaan emosional termasuk penurunan fungsi kognitif, memori (daya ingat) dan kelainan pada koordinasi motoric. Khusus pada penurunan fungsi kognitif, maka setiap perempuan menapouse dengan umur diatas 50 tahun pasti mengalami penurunan fungsi hormon estrogen.

Gangguan kognitif berupa gangguan memori dan atensi merupakan keluhan yang sering dilaporkan wanita yang mengalami masa menopause. Hal tersebut dipicu oleh penurunan dan fluktuasi estrogen selama masa menopause yang mendasari gangguan tersebut. Fluktuasi hormon terutama hormon estrogen juga memiliki efek pada regulasi suasana hati (mood) dan regulasi emosi di otak yang menyebabkan kecemasan pada wanita menopause dan secara signifikan mempengaruhi kualitas hidup. (Zulkarnain, 2015).

Penurunan kadar hormon estrogen akibat proses penuaan dapat menyebabkan fungsi kognitif mengalami cognitive ageing yang ditandai oleh adanya pelupa dan dapat menjadi mild cognitive impairment (MCI) dan dementia jika otak tidak diaktivasi secara optimal (Kim, Jung, 2015).

Menopause tidak seharusnya ditakuti dan dikhawatirkan oleh kaum wanita. Oleh karena itu, perlu dilakukan peningkatan kesehatan reproduksi karena hal tersebut memiliki andil penting dalam siklus kehidupan wanita pada masa menopause. Seorang wanita adalah sosok individu yang tangguh secara bio-psiko-sosial-spiritual, karena seorang wanita tidak hanya dapat merawat dirinya sendiri tetapi juga dapat merawat anggota keluarganya. Oleh karena itu, konsep pemberdayaan perempuan dalam kesetaraan gender bukan hanya memperjuangkan hak asasi manusia saja, tetapi juga perlu memperjuangkan kedamaian, kesejahteraan, dan ketahanan aspek bio-psiko-sosial-spiritual (United Nation, 2016). Hal ini penting karena jumlah perempuan terus meningkat hingga 1.1 milyar di dunia pada tahun 2025 (Schroeder, 2016).

World Health Organization (WHO, 2013). memperkirakan di tahun 2030 ada 1,2 milyar wanita yang berusia 50 tahun dan sebagian besar dari mereka (sekitar $80 \%$ ) tinggal di negara berkembang. Indonesia juga termasuk salah satu negara dengan populasi tingkat menopause yang diprediksi mengalami peningkatan lebih tinggi dari pada populasi di wilayah Asia dan global setelah tahun 2050 (Kementerian Kesehatan Republik Indonesia [Kemenkes RI], 2013). Menurut proyeksi penduduk Indonesia tahun 2006-2011 oleh Badan Pusat Statistik (BPS) jumlah penduduk perempuan berusia diatas 50 tahun meningkat dari 107 juta menjadi 373 juta orang, dan tahun 2025 diperkirakan akan ada 75 juta perempuan menopause (Badan Kependudukan dan Keluarga Berencana Nasional [BKKBN], 2013).

Hal tersebut menunjukkan bahwa menopause yang berdampak pada penurunan fungsi kognitif bagi wanita yang mengalaminya sudah semakin meluas di masyarakat. Oleh karena hal tersebut, maka diperlukan upaya untuk meningkatkan pengetahuan perempuan tentang dampak menopause yang mana salah satunya melalui pemberian edukasi atau pendidikan kesehatan. 
Pemberian edukasi dapat dilakukan melalui komunikasi baik secara lisan maupun tulisan yang dapat memengaruhi orang lain baik secara individu, kelompok, atau masyarakat sehingga mereka melakukan apa yang diharapkan oleh pelaku pendidikan (pemberi edukasi). Komunikasi yang digunakan berupa informasi yang didalamnya terdapat kenyataan- kenyataan yang perlu diketahui oleh penerima informasi sehingga dapat memahami nilai dari yang tidak tahu menjadi tahu. Oleh karenanya pemberian edukasi tersebut dilakukan melalui pengabdian kepada masyarakat.

Pengabdian kepada Masyarakat ( $\mathrm{PkM})$ dengan memberikan pendidikan kesehatan ini dilakukan di Gereja Protestan Indonesia di Bagian Barat (GPIB) Yudea. GPIB Yudea adalah gedung gereja yang dikunjungi oleh beberapa dosen yang ada di Fakultas Keperawatan Universitas Pelita Harapan dari berbagai wilayah sebagai partisipan berjemaat. Walaupun tidak secara rutin beribadah pada hari Minggu di Gereja Protestan Indonesia di Bagian Barat (GPIB) Yudea, namun kedekatan antara jemaat dan tim sebagai satu keluarga dalam tubuh Kristus sudah terjalin dengan baik. Hubungan harmonis dalam satu lingkungan keluarga Kristen merupakan karakter Kristus yang tercermin pada pertumbuhan iman Kristen yang dicirikan oleh ketekunan beribadah, kesetiaan dalam pelayanan kepada Tuhan dan kepada sesama, kesatuan hati dalam pergumulan, kebajikan dan komitmen melayani sesama.

Gereja Pentakosta Indonesia di Bagian Barat (GPIB) Yudea mempunyai 11 sektor pelayanan (sekpel) dan setiap sekpel mempunyai Pelayanan Kategorial Perempuan (PKP). Adapun anggota PKP adalah setiap perempuan yang sudah menikah atau belum menikah tetapi umur perempuan yang ikut terlibat dalam komponen pelayanan lebih dari 30 tahun. Berdasarkan informasi yang dituliskan dalam lembar Warta Jemaat, bahwa setiap minggu selalu ada perempuan menopause sebagai ibu rumah tangga yang mengalami berbagai jenis penyakit baik di rawat di rumah sakit ataupun tinggal di rumah. Berdasarkan hal tersebut maka tim penyelenggara PkM berupaya untuk meningkatkan pengetahuan masyarakat tentang dampak yang terjadi pada masa menopause melalui pemberian edukasi kesehatan.

\section{METODE}

Pelaksanaan pendidikan kesehatan tentang menopause dengan pendekatan diskusi dan tanya jawab untuk mengukur tingkat pengetahuan perempuan melalui teknik think-pair-sharing (pengukuran pengetahuan dilakukan secara pre. Think pair share merupakan model edukasi untuk berpikir, berpasangan dan berbagi, dengan tujuan agar peserta kegiatan mampu mendalami materi yang dibahas dengan lebih baik. Setelah itu dilakukan juga proses tanya jawab selama proses edukasi (post). Partisipan yang terlibat terdiri dari usia 30-74 tahun dan belum pernah dilakukan operasi pengangkatan organ sistem reproduksi.

Alur yang dilakukan dalam pelaksanaan kegiatan PkM diawali dengan melakukan audensi dengan pihak GPIB Yudea Tangerang untuk mengetahui informasi mengenai hari, tanggal, tempat dan sarana yang disesuaikan dengan kegiatan Pelkap PKP GPIB Yudea Tangerang sehingga pemberian edukasi dapat dilakukan. Sebelum Pendidikan kesehatan dimulai, maka para peserta diberikan satu lembar materi tentang tanda dan gejala menopause untuk dibaca dan diskusi dengan teman tentang tanda dan gejala menopause selama sepuluh menit. Setelah peserta selesai membaca materi, presenter memberikan kesempatan kepada satu orang peserta untuk menjelaskan ulang apa yang sudah dibaca dan diskusi dengan teman.

Adapun materi yang diberikan meliputi pengertian, tanda dan gejala, masalah yang mungkin timbul dan cara mengatasi masalah di rumah tangga terkait dengan menopause. Selain itu dijelaskan hubungan antara menopause dan kejadian penurunan fungsi kognitif pada perempuan akibat penurunan hormon estrogen pada perempuan menopause. Metode pendidikan kesehatan dilakukan dengan cara diskusi dan tanya jawab untuk memberikan kesempatan kepada responden langsung bertanya terkait dengan pengalaman. Media yang digunakan untuk memfasilitasi proses pelaksanaan pendidikan atau edukasi yaitu menggunakan laptop dan slide - LCD, microphone, materi, serta gambar-gambar yang relevan dengan materi. Penyampaian materi selama 100 menit sudah termasuk dengan pelaksanaan evaluasi selama proses. Evaluasi selama proses dilakukan 
untuk memberikan kesempatan secara langsung jika ada pertanyaan dan untuk mengetahui langsung keberhasilan proses pembelajaran setiap tujuan instruksional khusus yang disediakan diantaranya adalah pengertian menopause, tanda dan gejala menopause fisiologis, hormon yang terkait dengan kejadian menopause: kejadian fisiologi - patologis (akibat penyakit dan tindakan operasi), jenis gangguan sistem reproduksi perempuan yang dapat menimbulkan kejadian menopause dini, cara mengatasi masalah menopause di rumah tangga dan hubungan antara menopause dengan penurunan fungsi kognitif.

\section{HASIL DAN PEMBAHASAN}

Seluruh peserta $(n=45)$ dari 50 target peserta mengikuti kegiatan Pendidikan kesehatan dengan tekun. Hal tersebut dibuktikan dengan tidak adanya peserta kegiatan yang keluar masuk ruangan selama pelaksanaan kegiatan pendidikan kesehatan. Oleh karena itu, pelaksanaan kegiatan pemberian edukasi tentang kesehatan sistem reproduksi pada masa menopause dilakukan dengan lancar.

Rentang umur peserta yang mengikuti kegiatan pengabdian kepada masyarakat melalui pendidikan kesehatan terdiri dari usia 30 - 74 tahun, sehingga karakteristik usia peserta yang mengikuti kegiatan edukasi bervariasi. Para peserta lansia dipandu oleh tim pelaksana kegiatan pengabdian kepada masyarakat dari Fakultas Keperawatan Universitas Pelita Harapan untuk mengartikan setiap pertanyaan dengan menggunakan bahasa yang sederhana dan mudah dimengerti.

Seluruh peserta $(n=45)$ adalah perempuan sebagai pekerja atau ibu rumah tangga sesuai dengan karateristik inklusi umur 30 - 74 tahun dan tidak pernah dilakukan pengangkatan organ reproduksi. Rentang umur 30an merupakan masa tubuh mengalami keteraturan fungsi tubuh, namun kemudian mengalami penurunan fungsi sistem reproduksi perempuan (Nwankwo, 2014), sehingga perempuan umur 30 tahun dan belum pernah mengalami operasi atau pengangkatan organ sistem reproduksi diundang untuk mengikuti edukasi dan screening kesehatan sistem reproduksi.
Teknik yang digunakan pada proses preedukasi adalah bepikir, berpasangan dan berbagi (think-pair-sharing). Hal tersebut diawali dengan memberikan materi edukasi kepada peserta. Selanjutnya peserta yang diberikan materi membaca dan memahami isi materi tersebut dan setelahnya memberikan respon atas apa yang sudah dibaca di dalam materi tersebut (Rosita \& Leonard, 2013).

Pada proses pre-edukasi diketahui gambaran pengetahuan peserta tentang menopause dan kesehatan sistem reproduksi $(11,0 \%)$ melalui proses diskusi tanya jawab antara perempuan yang belum mengalami menopause kepada perempuan yang sudah mengalami menopause. Berdasarkan hasil pre edukasi artinya hanya ada sekitar $4-5$ peserta saja yang dapat menjawab setiap pertanyaan yang diberikan sebelum edukasi dimulai. Namun demikian sikap peserta sangat antusias pada diskusi pre-edukasi selama 10 - 15 menit yang dilakukan, bahkan setiap peserta mengikuti edukasi sampai selesai dan dilanjutkan dengan kegiatan konsultasi kepada tim terkait dengan kesehatannya. Sikap antusias yang ditampilkan oleh para peserta merupakan sikap positip perempuan menopause sebagai refleksi keterhubungan antara pengalaman 'empty nesting' dan kebebesan dimasa tua (Jack., Pitts., Riach., Bariola, 2014). Bahkan sikap antusias terhadap informasi baru diharapkan sebagai motivasi untuk membentuk koping positif ketika tubuh mengalami adapasi perubahan selama masa menopause (Koyuncu., Unsal., Arslantas, 2018).

Selama proses edukasi berlangsung, para peserta mengikuti dengan serius dan merespon melalui beberapa pertanyaan serta menjawab setiap pertanyaan yang diberikan oleh narasumber. Antusias peserta yang terlibat dalam kegiatan pengabdian kepada masyarakat melalui pemberian informasi edukasi kesehatan yang dilakukan membuat durasi edukasi bertambah karena jumlah pertanyaaan dari peserta semakin banyak dan terjadi diskusi diantara peserta dan narasumber. Para peserta yang bertanya dan dapat menjawab pertanyaan dari tim dengan benar diberikan rewards (33,33\%), artinya ada sekitar 15 peserta yang merespon selama proses edukasi. Proses edukasi tersebut merupakan sarana pemberian informasi kepada para perempuan, sehingga para perempuan umur 30 - 50 tahun yang belum mengalami 
menopause dipersiapkan adanya perubahan fungsi tubuh dan sekaligus memberikan penjelasan perubahan tubuh kepada perempuan menopause untuk beradaptasi terhadap perubahan tersebut. Seluruh peserta dengan sangat antusias mengikuti kegiatan Pendidikan kesehatan dibuktikan dengan aktif bertanya dan menjawab setiap pertanyaan yang diberikan selama proses pembelajaran berlangsung.

Pada akhir proses edukasi dilakukan kembali evaluasi untuk mengidentifikasi tingkat pengetahuan tentang menopause dan kesehatan reproduksi peserta. Data diketahui ada 10 peserta lagi yang dapat menjawab pertanyaan dengan benar $(22,0 \%)$ dan siap mengikuti screening kesehatan reproduksi setelah edukasi selesai dilakukan. Keadaan tersebut diyakini bahwa informasi yang diterima sudah dapat dipahami, sehingga keingintahuan akan informasi terkait dengan menopause menjadi bagian dari perempuan (Trudeau, et al 2011). Bahkan diketahui pada hasil penelitian lain yang sejenis yaitu karateristik umur, pekerjaan, paritas, dan pekerjaan tidak menjadi pembeda pada hasil proses pembelajaran pada perempuan menopause (Shafaie et al, 2014).

Berdasarkan hasil kajian sejak pre, proses, dan post edukasi diketahui bahwa hampir $70 \%$ peserta yang mengikuti Pendidikan kesehatan sudah memahami konsep menopause, sehingga peserta diharapkan mau menerapkan hasil edukasi yang didapatkan seperti melakukan olahraga setiap hari dan mengomsumsi makanan tinggi serat, protein, serta rendah lemak, menjaga diet dan pola makan dan gaya hidup sehat. Sesuai dengan fungsi olahraga pada perempuan masa menopause sebagai pilihan pengobatan alternatif untuk dapat beradaptasi dengan gejala psikologis, vasomotor, somatik dan seksual (Stojanovska, 2014).

Gambaran singkat pengetahuan menopause tersebut memberikan data hanya ada dua pertiga dari responden $(66,67 \%)$ saja yang mau mengikui screening dengan berbagai alasan. Pernyataan tersebut dijumpai pula pada responden perempuan menopause yang diberikan pendidikan kesehatan dan intervensi terapi hormon, namun tidak semua perempuan yang sudah memahami konsep tersebut mau mengikuti intervensi yang telah diberikan (Donati et al, 2013). Hal tersebut dapat dipahami bahwa pemberian informasi dalam waktu singkat dan tidak berkesinambungan tidak efektif terhadap perubahan sikap dan perilaku untuk informasi baru.

\section{KESIMPULAN}

Kegiatan Pengabdian kepada Masyarakat melalui pendidikan kesehatan pada perempuan menopause tentang screening kesehatan reproduksi di Tangerang yang dilakukan oleh tim Pengabdian kepada Masyarakat $(\mathrm{PkM})$ berjalan dengan lancar. Kerjasama antara tim PkM Fakultas Keperawatan dengan pihak Gereja Protestan Indonesia di Bagian Barat (GPIB) Yudea juga terlaksana dengan baik. Setiap peserta yang hadir juga merasa senang dan semakin memahami informasi tentang kesehatan reproduksi pada masa menopause.

Oleh karena itu, diharapkan kepada setiap peserta yang sudah mengikuti kegiatan pendidikan kesehatan di GPIB Yudea setelah mengetahui dan memahami dampak menopause pada tubuh maka setiap peserta mau melakukan screening kesehatan secara rutin terkait dengan sistem kesehatan reproduksi

Pada akhir acara, para peserta dan juga ketua tim GPIB Yudea mengatakan bahwa kegiatan yang telah dilakukan sangat bermanfaat dan dapat menjadi acuan bagi mereka untuk membantu meningkatkan derajat kesehatannya. Para peserta dan komponen pelayan dari Gereja juga menyarankan agar kegiatan dapat dilakukan dengan rutin sehingga mereka dapat memonitor kesehatan jemaatnya.

\section{UCAPAN TERIMAKASIH}

Kegiatan Pengabdian kepada Masyarakat ini didukung oleh Lembaga Penelitian dan Pengabdian kepada Masyarakat (LPPM) dan Fakultas Keperawatan Universitas Pelita Harapan. Tim PkM sangat berterima kasih atas kontribusi yang telah diberikan untuk pelaksanaan kegiatan pengabdian kepada masyarakat. 


\section{REFERENSI}

Ariyanti, H., Apriliana, E. (2016) Pengaruh Fitoestrogen terhadap Gejala Menopause. Dikutip pada http://juke.kedokteran.unila.ac .id/index.php/majority/article/view/914

Astutik, R. Y \& Suparni, I. E. (2016). Menopause, Masalah \& Penanganannya. Sleman: Deepublish.

BKKBN. (2013). Survei Demografi dan Kesehatan Indonesia 2012. BPS. Kemenkes RI. Agustus Vasishta, V.G. (2008). Quantum Magnetic Resonance Therapy (QMR): A novel palliative treatment for terminally ill cancer patients. diakses pada http://www.thejsho.com/pdf/quantum. pdf

Debby, A. 2012. Tesis Pengaruh Sikap dan Rangsangan Hasrat Seksual Terhadap Perilaku Seksual pada Wanita Menopause di wilayah Kerja Puskesmas Lingkar Barat Kota Bengkulu. Jakarta: STIKIM.

Dewi, M., K. (2018) Pengukuran Empat Faktor yang Mempengaruhi Tingkat Stress pada Wanita Menopause. Dikutip pada http://journals.stikim.ac.id/ojs_new/index.php/j iki/article/view/160

Donati, S., Satoli, R., Colombo, C., Senatore, S., Cotichini, R., Da Cas, R., Alegiani, SS., Mosconi, P. (2013). Informing women on menopause and hormone therapy: know the menopause a multidisciplinary project involving local healthcare system. Open Access. PLOS. [internet]. Disitasi pada tanggal 11 Januari 2019. Dapat diakses https://journals.plos.org/plosone/articleid= 10.1371/journal.pone.0085121

Epperson, C.,N., Shanmugan, S., Kim, Deborah, R., Mathews, S., Czarkowski,K.,A., Bradley, J., Appleby, D.H., Iannelli,C., Sammel,M.D., Brown,T.,E. (2015). New Onset Executive
Function Difficulties at Menopause: a Possible Role For Lisdexamfetamine.

Henderson, Victor, W. 2009. Menopause, Cognitive Ageing and Dementia: Practice Implications. USA: Standford University.

Jack, G., Pitts, M., Riach, K., Bariola, E., Schapper, J., Sarrel, P. 2014. Women, Work and the Menopause: Releasing the Potential of Older Professional Women. LA TROBE. [internet]. Diakses tanggal 28 Agustus 2019. https ://core.ac.uk/download/pdf/30673673.pdf

Kementerian Kesehatan Republik Indonesia. (2013). Gambaran Kesehatan Lanjut Usia di Indonesia.

Kim, S.A, Jung, H. (2015). Prevention of cognitive impairment in the midlife women. pISSN: 228 pISSN: 2288-6478, eISSN: 2288-6761 http://dx.doi.org/10.6118/jmm.2015.21.1.19 Journal of Menopausal Medicine 2015;21:19-238-6478, eISSN: 2288-6761

Koyuncu, T., Unsal, A., Arslantas, D. 2018. Evaluation of the Effectiveness of Health Education on Menopause Symptoms and Knowledge and Attitude in Terms of Menopause. Journal of Epidemiology and Global Health. 8(1-2), pp. 8-12. DOI: 10.2991/j.jegh.2018.08.103. ISSN 22106006.

Nwankwo, C.U. 2014. Knowledge and attitude of women towards menopause in Anambra State. International Journal of Latest Trends in Engineering, Science and Technology, Volume 1, Issue 7. ISSN: 2055-530X. [Internet]. Diakses tanggal 28 Agustus 2019. https://www.researchgate.net/publication/2 78686196

Rosita, I., Leonard. (2013). Meningkatkan Keja sama Siswa Melalui Pembelajaran Kooperatif Tipe Think Pair Sharing. Dikutip pada https://journal.lppmunin dra.ac.id/index.php/Formatif/article/view/1 08/105

Schroeder, S.A. (2016). Health, disability, and well-being. Routledge Handbook of 
Well-Being, ed. Fletcher. diakses https://philpapers .org /rec/ SCHHD A-10

Shafaie, FS., Mirghafourvand, M., Jafari, M. (2014). Effect of education through support group on early sympthom menopause: a randomized controlled trial. Journal of Caring Sciences, 2014 , $3(4)$, 247-256 doi:10.5681/jcs.2014.027 http:// journals.tbzmed.ac.ir/ JCS

Susilowati, L., Istianah, U. (2012). Fungsi Kognitif Menentukan Kualitas Hidup Lansia

Stojanovska, L., Apostolopoulos, V., Polman, R., Borkoles, E. (2014). To exercise or not to exercise, during menopause and beyond. Diakses pada https://www.sciencedirect .com/science/article/pii/S037851221400025

Tan, M.N., Kartal., Guldal,D. (2014) The Effect of Physical Activity and Body Mass Index on Menopausal Symptoms in Turkish Women. BMC Women's Health
United Nation. (2016). Human Development Report 2016: Human Development for Everyone. Sales no.: E.16.III. B.1. ISBN: 978-92-1126413-5. eISBN: 978-92-1-060036-1. ISSN: 0969-4501

Zulkarnain. 2015.Peran Latihan Fisik Teratur Terhadap Fungsi Memori dan Kognitif Wanita Pasca Menopause. Jurnal Sport Pedagogy 